\title{
The practical guidelines on the impact of mahadi [bride price] on the young Basotho couples prior to marriage
}

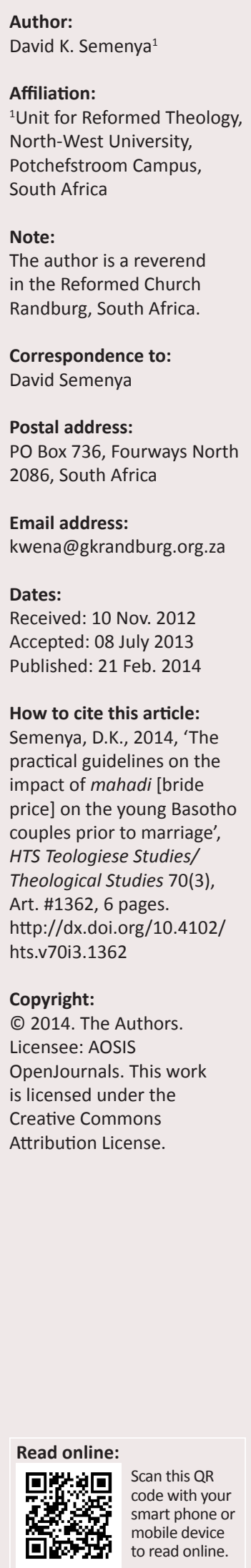

This article investigates and provides guidelines to the negative impact of mahadi on the Basotho youth before they may marry. It is important to note that marriage is one of the main parts of the life cycle amongst the Basotho and not only joins a man and a woman together, but is also considered to unite the members of the respective families of the married couple into one family. This union of two families comes into effect when the process of negotiation of the mahadi is initiated. The negotiation for mahadi is, in other words, the first stage of bonding two families together. In the hope of gaining a better understanding and results, the writer searched for a qualitative method to conduct the research.

\section{Introduction}

Boshego (2006:113) states that marriage amongst the Basotho is viewed as a union between two individuals and also the joining together of a number of families, through a variety of rituals, one such is magadi [bride wealth]. Equally important, Nyirongo (1997:111) asserts that marriage amongst Africans is a means of gaining or enhancing social status within the family and tribe. This status is achieved through the bearing and rearing of children. Becoming a spinster or a bachelor invites ridicule - not only by relatives but also by the community at large.

In reference to the above, Letšosa and De Klerk (2008:11) add that by remaining unmarried the bachelor is thereby setting his life in linear time and following a straight path that eliminates any possibility of returning as an ancestor. He would, therefore, not be able to reproduce himself through children. Marriage is considered the focal point of existence and is the point where all the members of a given community meet the departed, the living and those yet to be born, thereby repeating, renewing and revitalising history. Hence marriage is one of the main parts of Basotho life cycle (cf. Figure 1). Community members are expected to participate in the marriage ceremonies (Boshego 2006:118). Marriage is more than a physical relationship to Africans, it has eternal consequences. Remaining unmarried is to cease living both now and in the hereafter. Marriage establishes the essentials in life and in death (cf. Turaki 1999:225). However, a certain process has to be followed therefore before entering into marriage in Basotho culture.

\section{The mahadi factor}

There are a number of factors ${ }^{1}$ that constitute marriage amongst the Basotho (cf. Figure 2). This article will however, only concentrate on one element, namely mahadi. ${ }^{2}$ Lobola is an age-old African custom that is as alive today as it was a hundred years ago (Smith 2002). It is important to realise that there is no evidence to suggest that it will ever disappear from African culture, since even the most high-profile members of society, like Nelson Mandela who paid 60 cows to marry his beautiful wife Graca Machel, practice the custom. It is a form of cultural heritage (African National Congress Daily News 2008). Mupotsa (2008) takes a positive view and explains that lobola is a means to a goal, namely a process or negotiation that results in the coming together of two families - a means of legitimising the union between two people.

In these modern days lobola is tightly linked with education and again with the suitability of a partner especially in terms of price. According to Kaufman, De Wet and Stadler (2001:153) the standard cost of magadi in the olden days was about 12 cows for the bride which currently would be equivalent to R10 000. The bride price is increased each year and Mwamwenda and Monyooe (1998:269) confirm that a decade ago a husband would pay R20 000 for magadi to marry his

\footnotetext{
1.Some of the factors that constitute a marriage according to the Basotho are: (1) the children in a marriage (the marriage is not considered legitimate untill children are born); (2) the in-laws (the in-laws are the key players in the lobola negotiations); and (3) the lobola, which
} the subject of this article.

2.Lobola can also be referred to as mahadi or magadi in Southern Sotho, Pedi and Tswana respectively or bride price in English. These words will therefore be used interchangeably throughout the article, whether the word lobola or mahadi is used, the essence is still the same. The main reason is that the word lobola, associated with Nguni languages, is mostly used amongst the Sotho nations. Hence it is found that most of the African writers are using the word lobola more often than Mahadi. 


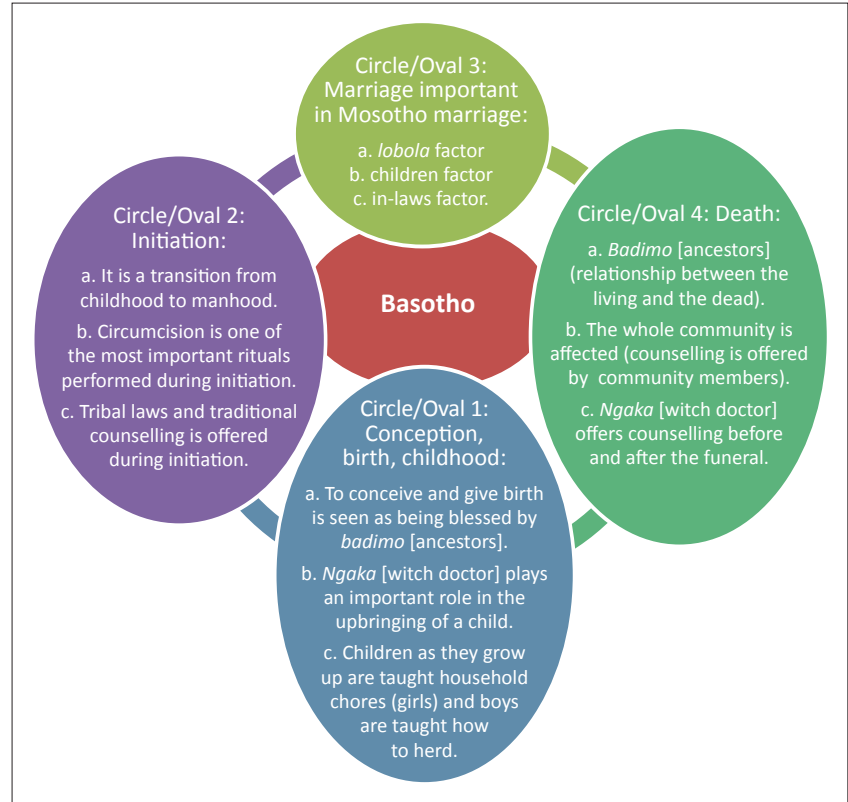

FIGURE 1: Basotho life cycle.

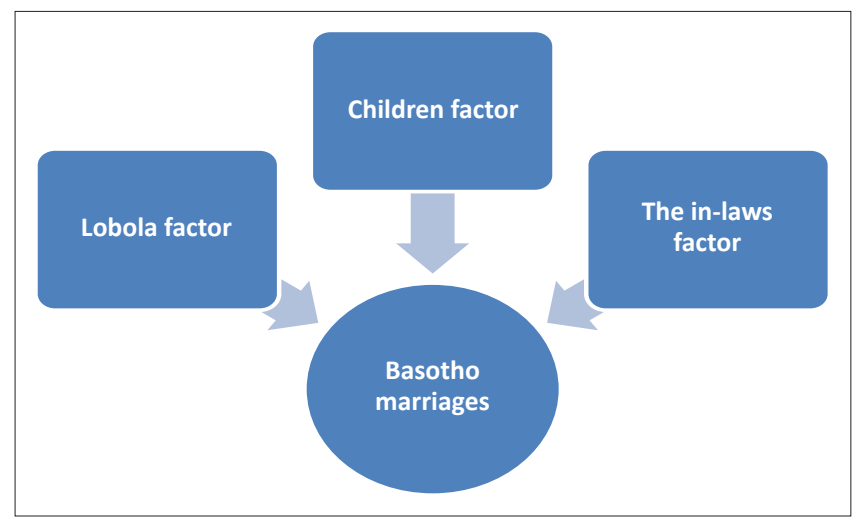

FIGURE 2: Factors constituting Basotho marriage.

wife. On the same note, City Press reported that Stats South Africa's technical manager of census data processing, JeanMarie Hakizimana (2012), said that people are rather living together than spending their money on expensive weddings. This is followed by a report that in the current situation one would pay up to R120 000 for magadi and the wedding. This shows how the bride price has increased from six centuries ago until today.

Education is linked to the access to employment. Therefore educated women are likely to find jobs that pay relatively well and are usually valued more highly at lobola negotiations than the uneducated women (Kaufman et al. 2001:153). When one analyses the above argument, the observation could thus be made that the whole idea of high bride prices could influence men negatively as paying high mahadi can in a way be interpreted as buying women and thus making women part of men's property, which is not true (cf. Mwamwenda \& Monyooe 1998:25).

Moreover, Madikwa (2012) of the Sowetan recently reported that most young men argue that lobola and the economic situation were the greatest discouragement for them to settle down. But Nkosi Mwelo Nonkonyana, the leader of The Congress of Traditional Leaders of South Africa (Contralesa) dismissed this as untrue (Madikwa 2012). Nonkonyama said young men who feared responsibility always sighted lobola as a problem. He said lobola should never be a deterrent in the African tradition as it was not about material goods. Nonkonyana further argues that ' $[i] \mathrm{t}$ is only those irresponsible men who do not want to get married that come up with such excuses' (Madikwa 2012). Modo (1999:379) confirms this when he says that the high bride price can never prevent a man to marry the woman he loves since the mode of payment can be negotiated to suit both families. The Sotho saying that says: 'Monyala ka pedi o nyala wa hae' [Two cattle would suffice for a man to marry the woman of his choice] confirms this as well.

Furthermore, Smith (2002) argues that it is precisely the joining of two families that makes the payment of lobola so important to marriage. The custom weaves a mutual respect and dignity between the families, whereby the love between the man and the woman is expanded to include the immediate and the extended families. It is a formal process and requires strict adherence to protocol, whereby the negotiations must be conducted in writing and necessitate the physical presence of both families. A quick visit or telephone call does not suffice. Negotiations could take days and talks centre around the number of cattle that will make up the bride price.

Nyirongo (1997:114) adds that lobola serves as proof that the marriage is legally recognised and accepted by both the immediate families and also the community at large. The husband can only claim the woman as his wife and the children his offspring if lobola is paid in full, otherwise the wife's family may claim the children as their own should the couple separate. In contrast thereto Letšosa and De Klerk (2008:12) argue that the couple is deemed to be husband and wife as soon as the lobola has been agreed and the first instalment has been paid. The researcher agrees with the view taken by Letšosa and De Klerk, as opposed to that of Nyirongo, because in the researcher's experience a Mosotho ${ }^{3}$ man does not need to pay the magadi in full to claim the wife and children as his own. There is even a saying in this regard, which states 'Magadi ga a fele' [the dowry is never paid in full]. Whether magadi is paid in full or not, the couple is deemed to be married within the Basotho context.

Although the payment of mahadi in the form of cattle is considered the custom of the past, there are still, even in these modern times, instances where mahadi is paid with cattle. Smith (2002) confirms this, but explains that there is a modern variation on this theme. Most often the talk is about money, rather than cattle. Cattle are symbolic and represent certain amounts of money. Ansell (2001:703) argues that the reason for that is because Basotho are trying to reconstruct their cultural identity as an example of 're-traditionalism'. This is particularly the case for historical reasons, wishing to retain a separate political identity even when money is given in place of cattle it is still referred to as 'cattle'. Once the mahadi 3.A singular of Basotho. 
is established, the negotiations are formally over. According to the writer's experience magadi is always accompanied by another item, such as a knife, jacket, stick, blanket, et cetera and these could also be represented by money.

The above discussion can be summarised and the conclusion drawn is, that mahadi is of great importance to Africans and the Basotho in this particular context. This may indeed be the case, but it remains the author's contention that this process has an adverse affect on the life of a Basotho young couple prior to marriage.

Before proceeding to the empirical research, a number of aspects ${ }^{4}$ related to the mahadi negotiation first need to be elucidated to ensure a clear understanding of the custom. The process proceeds as follows:

\section{Bommaditsela [representatives]}

Semenya (2010) states that the lobola negotiators, of both the wife and the husband, are called bommaditsela. The families are usually represented, on both sides by the malome [uncle] and rakgadi [aunt]. Upon arrival at the bride's home, the bommaditsela [negotiators] become bakgonyana (as representatives of the prospective son-in-law, they are housed in a secluded place to relax undisturbed). They then convey their purpose to the woman's family with expressions such as 're tlile o kgopela sego sa meetse' [We are asking a gourd of water-meaning we are here for lobola negotiations].

According to the researcher's experience the roles of the bomalome [uncle] and borakgadi [aunt] do not end with negotiating magadi. They are also expected to offer traditional counselling to the couple, prior to and subsequent to the marriage (should the couple encounter difficulties) according to Basotho culture.

\section{After the mahadi agreement is reached}

Once the mahadi negotiations have been completed between the two families, the rakgadi [aunt] will call the woman or makoti (Mupotsa 2008) who will refrain from speaking or greeting the bakgonyana [the prospective in-laws] until they pay a 'pula molomo' [a mouth opener]. The bakgonyana [the prospective in-laws] will place the money on the table and if she is satisfied with the amount on the table, only then will she greet. Her family's representatives will then ask whether she knows the people, which she will confirm - since she would have agreed with her fiancé that his representatives would visit them around a certain date.

Thereafter, the bakgonyana [the prospective in-laws] will start asking their makoti [a question], which is usually whether she has been damaged (that is to say, whether she

4.The writer wants to state it clearly that the mahadi negotiations processes or steps may differ greatly between the Sotho nations (Tswana, Pedi and Southern Sotho) however the goal and the essence is the same. To mention but a few there are similarities in this regard: Both nations use representatives for negotiating mahad the bride price is expected by both Sotho nations and also the naming of a bride. Dissimilarities. The Tswanas and the South Sotho give the bride utensils for her own use at her husband's home and the Pedi's use Go hlabiša as a rubber stamp that they complied with all requirements of magadi. has been pregnant or whether she is pregnant at the time of negotiations). If the answer is yes, then the charge for damages incurred is subtracted from the magadi. When this has been done, bakgonyana [the prospective in-laws] leave the home.

\section{'Go kgopela ngwetši' [asking of a bride after the lobola agreement]}

It should be remembered that not all aspects of this African custom have been recorded. The oral tradition still plays an essential role in many regards. According to the research conducted, the bakgonyana [the prospective in-laws] will then arrange another visit to the fiancé's home and request the bride to come and stay with her fiancé, which is called 'Go kgopela ngwetši'. The rakgadi [aunt] of the fiancé will accompany the bride to the fiancé's home, at the agreed date.

According to the researcher the bride is first counselled by the rakgadi [aunt], before she is accompanied to the groom's home which is called 'Go laya'. Normally the groom has already received counselling from the malome [uncle] who negotiated the mahadi for him. Upon arrival at the groom's home, the groom's family will invite their neighbours to come and enjoy 'bogobe ba ngwana' [porridge for a child, but meaning that the bride has arrived] and after the meal the groom's family will go to the mošate [traditional house] to perform the 'go soma ngwetši' [letting the king know about the new member in his village]. This will be followed by a white wedding eventually. Some couples may only perform this ceremony 20 years after the traditional marriage, irrespective of their time together as a couple. The registration of the marriage is also the couple's responsibility.

\section{'Go phahlela' [the giving of utensils to the bride]}

When the bride is accompanied to the home of her husband, she is given utensils from her own home for use at her husband's home. These usually consist of a traditional broom, blankets, a basin, a dish and spoons. This is done because at that time she will not yet know where to find these items in her new home in order to perform the expected tasks of waking up early in the morning to sweep the ground in and around the house, to prepare food and such like (the in-laws may even intentionally hide their broom). She may not wake anyone to find out where such items are kept. She will learn this as time passes (Semenya 2010).

\section{'Go hlabiša' (a sheep, cow or goat slaughtered for the bakgonyana [the prospective in-laws] as proof of having complied with all the bride's demands)}

The tradition where the fiancé's family slaughters a sheep or a goat as an expression of thanks to those family members who completed their task as bakgonyana [the prospective inlaws] and complied with all the demands of the bride.

According to Molapata (2005:51) the purpose of this ritual, amongst others, is to spill the blood of the slaughtered animal and this is believed to be a method of communicating with 
the ancestors informing them about the impending marriage. The ritual also strengthens the bond between the two families and their ancestors. The bakgonyana [the prospective in-laws] are given the animal to slaughter and after slaughtering, they take the head and the skin as proof of having complied with all the demands of the bride's parents. They are also entitled to a piece of meat cut from the animal, which is normally a whole limb of the animal. The rakgadi [aunt] then relates the purpose of molato [invitation], which is called 'go ba tšhela $k a$ di taba' [tell them the purpose of the invitation], since this invitation is extended to those members of the community who didn't attend the mahadi negotiations.

\section{Naming of the bride}

Amongst the Basotho marriage changes the status of both men and women in society, along with the corresponding rights and privileges. The new bride is therefore given a teknonymous name to keep her in-laws from addressing her or referring to her by her maiden name. The husband is also expected to call her by this name, particularly amongst family and in public. The teknonymous name may become permanent and as such her firstborn's name will often match her teknonymous name - for example, if the bride is named Mmatshepo, her boy child will be called Tshepo [trust] and her daughter Tshepiso [promise] (Guma 2001:272).

According to the researcher's experience, teknonymous names for Pedis' are mostly given at a traditional marriage ceremony and more often than not at the 'white wedding'. This, however, differs between the various Basotho groups - for example, the Southern Sotho bestows the teknonymous name on the bride immediately upon arriving at the groom's home. Even if the mahadi has been paid in full the married couple must have a white wedding so that the bride may receive a teknonymous name, which is of great importance amongst Sotho wives. Couples which have already been married for more than a decade, may still have a white wedding in order for the wife to receive her teknonymous name - as it is a source of pride amongst married Sotho women.

\section{Research methodology}

Three different Sotho reformed congregations were selected, namely one from the Northern Sotho-speaking congregations, one from the Setswana-speaking congregations and one from the Southern Sesotho-speaking congregations. The participants included a minister, an older man, an older woman, a young man and a young woman from each congregation to ensure a broader perspective. The names of the congregations and participants will remain anonymous for the sake of confidentiality. The author wants to state that all the participants gave consent for their responses to be published.

Five people per congregation were interviewed: one man, one woman, one young male, one young female and a minister. The following symbols denote the different categories, for ease of reference and technical purposes:
- Congregation:

- Classis North-West in Makwasie Lebaleng hereafter referred to as the North-West congregation.

- Classis Free State in Virginia hereafter referred to as the Free State congregation.

- Classis Limpopo in Ga-Ramongoana village hereafter referred to as the Limpopo congregation.

- Interviewees:

- $\mathrm{MM}=$ mature man

- $\mathrm{MW}=$ mature woman

- $\mathrm{YM}=$ young man

- $\mathrm{YW}=$ young woman

- $\mathrm{REV}=$ the minister of the congregation or reverend.

The following two questions were posed: What role does mahadi play in marriage? And secondly: What impact does mahadi have on Basotho youth? (cf. Box 1).

\section{The findings}

The participants' responses to the role mahadi plays in marriage were as follows:

The mature male (MM) of the North-West congregation stated that mahadi is beneficial when the marriage ceremony is held at the bride's home. The mature woman (MW) of the North-West congregation lamented the fact that the bride price is spent on goods that will be used by the bride and groom at her prospective husband's home. The young man (YM) from the North-West congregation however, explained that the bride price is indeed of major importance, since the groom pays for the expenses the bride's parents incurred in raising her. The young female (YF) of the North-West congregation felt that since the man is buying a wife, the bride's parents should receive payment - whether in cows or money. The Reverend (REV) of the North-West congregation added a slightly different perspective by mentioning that mahadi pays for the wedding and also for the goods the bride takes to her husband's home.

According to the MW of the Free State congregation, magadi is an expression of gratitude to the parents of the bride, which she explained is a way of making the groom pay for the expenses that the bride's parents incurred in raising their child. In correspondence with the above, the YM of the Free State congregation noted that it is not only an expression of gratitude to the bride's parents, but also a method of uniting the two families. The YF of the Free State congregation said that magadi is the custom of providing the bride with the necessary goods in her husband's household. The REV of the Free State congregation once again emphasised that magadi is an expression of gratitude to the bride's family.

BOX 1: Questionnaire.

Five people per congregation were interviewed: one man, one woman, one young male, one young female and a minister.

The following questions were posed:

1. What role does mahadi play in marriage?

2. What effect does mahadi have on the Basotho youth? 
The MW from the Limpopo congregation explained that the bride price is the custom that she does not think should be done away with, since no woman can just let her daughter be married for free. According to the MW of the Limpopo congregation, it lays a foundation of friendship between these families. The YF of the Limpopo congregation said that the custom unites both families and it also honours the bride's family for their efforts in raising their child, to which the YM of the Limpopo congregation added that magadi is a reflection of marriage and is a sign of respect to the groom's family. The YF and REV of the Limpopo congregation reiterated that it is a method of honouring the bride's family for their efforts in raising her.

The participants' responses on the impact of mahadi on the Basotho youth, prior to marriage are as follows:

The MM of the North-West congregation could find no problem with mahadi, whilst the MW from the same congregation emphasised the lack of benefit to the bride's parents. The YM of the North-West congregation argued that although mahadi plays a major role in reimbursing the bridegroom for expenses, it unfortunately delays marriage amongst the youth. In contrast, the YF of the North-West congregation stated that mahadi is not a negative custom at all, since it is an expression of gratitude towards the bride's family. The REV of the same congregation added that although it is a customary practice that is not likely to stop anytime soon, the parents of both families should not make it difficult for their children to marry just because of mahadi.

The MM from the Free State congregation also praised this custom, refuting that it has any adverse impact on the youth and their intention to marry and the MW of the same congregation said it is our culture and mgadi should stay as it is. The YM of the Free State congregation argued that the parents of the bride-to-be are actually selling their children through magadi. In agreement with YM from the Free State congregation, the YF said magadi denies them an opportunity to get married since their parents charge more for magadi. Correspondingly the REV form the Free State congregation explained that this practice affects the church in many ways, because the members of the church consist of young couples who are unmarried and engage in sex before marriage.

The MM of the Limpopo congregation said the practice is good and there is nothing wrong with it. He furthermore stated that he himself adhered to the custom when he married his beautiful wife and all things went well. MW from the Limpopo congregation explained that there was nothing wrong with magadi, since it serves as proof that one has been married. The YF of the Limpopo congregation argued strongly that the only way for a man to claim her is when the groom's parents followed the procedure in paying magadi for her. She further argued that otherwise there would be no marriage. The YM of the Limpopo congregation said that magadi is expensive nowadays and the result is that they no longer have any interest in marrying their loved ones and therefore they engage in premarital sexual activities. The
REV of the Limpopo congregation explained that the practice has an impact on both members of young couples especially when the bride price is too high.

\section{Discussion}

As mentioned, the Basotho consider marriage as one of the most important parts of life and the positive view of mahadi, as the method of joining two families is not surprising. The research reflected on the beneficial aspects of mahadi as its expression of gratitude towards the family of the bridegroom and the bond it develops between the two families upon entering into negotiations.

It is important to remember that God instituted marriage, as shown in Genesis 2:18-25, when God saw that it was not good for man to be alone. God did not seek man's opinion on marriage but created a partner for him. Not only a member of the opposite sex, but a suitable partner from his own flesh. Neither did God wait on the man to decide whether he would like this partner, but took the woman to the man. It could therefore be argued that marriage should take place according to God's plan and not the stipulations of tradition.

From the general view of the participants in the research, magadi has a negative influence on the social, economic and as well as the faith for the young couple prior marriage. The reasons that could be given are that most of the participants mentioned above wanted to honour marriage, but they could not do so, because of the high bride price that they might have to pay before marrying their loved ones. This becomes evident when mahadi is too expensive to afford.

In addition to that, the faith of the young couples who want to marry and cannot afford magadi is tested on a regular basis. Therefore the young couples find themselves facing a difficult situation on whether to honour God by not engaging in premarital sex or just to go along with their feelings. Moreover this of course does not only negatively affect the young couples but the society as a whole including the church. In the end the moral behaviour of the members of the society as a whole deteriorates.

Looking at the participants' argument, most of them argued that parents consider mahadi a reimbursement for the expenses they incurred in raising their daughter and that is the reason why a number of respondents labelled it a business in which the bride's parents are essentially selling their children. Another negative aspect is the couples' tendency to delay marriage, opting to cohabit and thus engage in premarital sex.

The questions that may arise from the above negative findings may be: What happens then when mahadi stands in the way of the young Basotho couples to get married? Should they just accept the fact that they cannot afford mahadi and can, therefore, not marry? As noted above, marriage is an institution of God and as such the will of God should take priority in issues relating to marriage. Paul urges the unmarried and widows in 1 Corinthians 7:8-9 to remain unmarried but adds, 
that should they not be able to control themselves it would be better for them to marry, than burn with passion. This leads to the conclusion that mahadi should not hinder anyone from getting married. It could furthermore be argued that burning with passion may lead to immoral practices, like cohabiting and engaging in premarital sex which God condemns. The researcher can in no way condone the aforementioned sins, because burning with passion simply does not grant anyone license to live an immoral life.

\section{Conclusion}

The above shows that marriage is an important part of life to the Basotho. Mahadi is considered the vehicle through which to seal agreements of marriage. Although this may be true, the fact remains that marriage is from God and not man, and as such man should always honour God above culture, especially when culture is in conflict with God's will.

Additionally, a point that is often overlooked is how God's will is sometimes not the priority when dealing with marital issues and for that reason couples often refrain from marriage when unable to observe certain cultural practices. The principles given below are sure to assist the church in dealing with the effects of mahadi on the young Basotho couples prior to marriage.

\section{Practical guidelines for mahadi}

Since mahadi is a practice that is unlikely to disappear from Basotho culture, the church council should at least launch programmes in which members are taught to refrain from abusing the essentiality of magadi, by making it difficult for couples to enter into the holy matrimony that God instituted. The church council must also develop a marriage programme (MEP) that will assist the congregation to adhere to marital principles, as described in the Bible.

Additionally, mini conferences that focus on the essentiality of marriage and its challenges (such as mahadi) need to be organised more regularly. This will make the congregants aware of the trends they may face upon entering into holy matrimony.

By the same token, the church council should at least identify couples impacted by the mahadi factor and counsel them in a way that will lead to an agreement between both sets of parents and that will honour marriage.

Equally important is arranging premarital counselling courses. This will enable the minister of the Word to identify possible problems associated with mahadi and thereby employ the knowledge he possess to timeously assist such couples, before pronouncing them qualified to marry.

\section{Acknowledgements Competing interests}

The author declares that he has no financial or personal relationship(s) that may have inappropriately influenced him in writing this article.

\section{References}

African National Congress Daily News, 2008, 'Mandela-marriage, diamond: Anniversary doubles Mandela's 90th birthday joy', Sapa-AFP, 15 July, viewed 20 May 2009, from http://70.84.171.10/etools/newsbrief/2008/news

Ansell, N., 2001, 'Because it's our culture! (Re) negotiating the meaning of Lobola in the Southern African Secondary Schools', Journal of Southern African Studies 27(4), 698-716. http://dx.doi.org/10.1080/03057070120090691

Boshego, L.P., 2006, 'Manifestation of cultural diversity in the novel: Megokgo ya lethabo - Tears of Joy', South African Journal of African Languages 26(3), 1-13.

Guma, M., 2001, 'The meaning of names amongst Basotho of Southern Africa: A historical and linguistic analysis', Nordic Journal of African Studies 10(3), 265-279.

Hakazimana, J., 2012, 'Census 2011: South Africa's changing families', City Press, viewed 07 May 2013, from http://www.citypress.co.za/news/census

Kaufman, C.E., De Wet, T. \& Stadler, J., 2001, 'Adolescent pregnancy and parenthood in South Africa: Studies in family planning', Reports 32(2) 147-160.

Letšosa, R. \& De Klerk, B., 2008, 'Liturgical aspects of wedding ceremonies in Reformed churches of African Origin', Journal of Theology and Religion in Africa 33(1), 1-24.

Madikwa, Z., 2012, 'Ilobolo is meant to be token that unites African families', Sowetan, 15 February, viewed 20 September 2012, from http://www.sowetanlive.co.za/ news/2012/02/15/ilobolo-is-meant-to-be-token-that-unites-african-families

Modo, L.V.O., 1999, Dual legal system, Basotho culture and marital stability, Department of Sociology/Anthropology, University of Uyo, Akwa Ibom, State of Nigeria.

Molapata, B.T., 2005, 'Customs and rituals', masters dissertation, Department of Sociology, University of South Africa.

Moputsa, D.S., 2008, 'Lobola for my love', Mail \& Guardian, 23 July, viewed 20 May 2009, from http://www.mg.co.za/article

Mwamwenda, T.S. \& Monyooe, L.A., 1998, 'Do African husbands own their wives?', Psychological Reports 82, 25-26. http://dx.doi.org/10.2466/pr0.1998.82.1.25

Nyirongo, L., 1997, The gods of Africa or the God of the Bible?: The snares of African traditional religion in Biblical perspective, Potchefstroom University for Christian Higher Education, Potchefstroom.

Semenya, D.K., 2010, 'A biblical framework for counselling as an alternative for traditional Sotho counselling on the life cycle', PhD thesis, Department of Practical Theology, North-West University.

Smith, G., 2002, 'Marriage tradition in Africa: Lobola', in Essortment, viewed 20 May 2009, from http://www.essortment.com/marriage-tradition-africa-lobola-36599.html

Turaki, Y., 1999, Christianity and African gods: A method in theology, Potchefstroom University for Christian Higher Education, Potchefstroom. 